DOI: $10.2478 / \mathrm{v} 10025-007-0008-4$

JOURNAL OF WATER

AND LAND DEVELOPMENT

J. Water Land Dev. No. 10, 2006: 91-106

\title{
Object-oriented classification of Landsat ETM+ satellite image
}

\author{
Stanisław LEWIŃSKI
}

Instytut Geodezji i Kartografii, ul. Modzelewskiego 27, Warsaw, Poland, tel. 0 (22) 329-19-76, e-mail: stanislaw.lewinski@igik.edu.pl

\begin{abstract}
This paper presents results of object-oriented classification of Landsat ETM+ satellite image conducted using eCognition software. The classified image was acquired on 7 May 2000. In this particular study, an area of $423 \mathrm{~km}^{2}$ within the borders of Legionowo Community near Warsaw is considered.

Prior to classification, segmentation of the Landsat ETM+ image is performed using panchromatic channel, fused multispectral and panchromatic data. The applied methods of classification enabled the identification of 18 land cover and land use classes. After the classification, generalization and raster to vector conversion, verification and accuracy assessment are performed by means of visual interpretation. Overall accuracy of the classification reached $94.6 \%$. The verification and classification results are combined to form the final database.

This is followed by comparing the object-oriented with traditional pixel-based classification. The latter is performed using the so-called hybrid classification based on both supervised and unsupervised classification approaches. The traditional pixel-based approach identified only 8 classes. Comparison of the pixel-based classification with the database obtained using the object-oriented approach revealed that the former reached $72 \%$ and $61 \%$ accuracy, according to the applied method.
\end{abstract}

Key words: object-oriented classification, land use, Landsat ETM+

\section{OBJECT-ORIENTED CLASSIFICATION}

In the 1990s, the development of new classification methods did not go along with the progress in the field of techniques of obtaining satellite images. The most modern, high-resolution images were, and still are, processed using classification algorithms, whose basic assumptions were defined in the 1970s (BLASCHKE et al., 2000). It was only in the end of 2000 that the first commercial software for objectoriented classification eCognition was introduced as the first application to change the principles and capabilities of classification (BAATZ et al., 2001).

In the case of the object-oriented classification, the analysis is not focused on single pixel values, but on entire groups of pixels which meet the preset homogene- 
ity criteria. Such groups of pixels are called objects. They are created in the course of the segmentation process, which precedes the classification. Segmentation is not a new concept of satellite image processing. It is one of the most fundamental processes preceding the analysis of image data, which was initially connected mainly with pattern recognition. GONZALEZ and WINTZ (1977) state that the aim of segmentation is to divide the image content into so-called regions that are significant for analysed phenomenon. Currently, segmentation is not associated with regions but with the so-called objects. SCHNEIDER and STEINWENDER (1999) define an object as a group of pixels of particular significance, almost in the same way as in the case of a region.

The eCognition software involves the "fractal Net Evolution" segmentation procedure, elaborated by the Delphi2 Creative Technologies company (BAATZ and SCHAPE, 1999). The patented algorithm of the segmentation process uses parts of the fractal and neural network theory and creates a hierarchical structure of semantically connected objects.

Basic assumptions of the multi-level segmentation method applied in the eCognition software are described by BAATZ and SCHAPE (2000). This method is characteristic for its high universality, from the perspective of data and possible application. Designers of the method focused on solving the problem of the scale of the analysed phenomenon and repeatability of results and emphasised the optimisation of calculations, which is significant in the cases of large image sets.

Segmentation starts from single pixels, whose groups form larger objects. Decisions on merging the pixels are determined by the homogeneity criterion, with a preset threshold value of the scale coefficient. The homogeneity criterion is also defined by the color and shape parameters, connected with spectral values and the shape of the object. Additionally, the shape criterion is further divided into two subcriteria, associated with the smoothness and compactness parameters (eCognition, ver. 3).

The algorithm used in the eCognition software enables multi-level segmentation. Higher levels contain larger objects, created on the basis of lower-level objects. Their borders go along the borders of lower-level objects. It is also possible to perform new segmentation between the already existing layers. When generating particular segmentation levels, it is possible to adjust the analysed spectral channels, their weight, scale coefficients and homogeneity criteria. It enables the elaboration of diverse object creation strategies, depending on the goal we want to achieve.

The classification of objects is based on enquiries addressed to the database created by the segmentation process (DE KOK et al., 2000). Each object can be defined on the basis of features connected with its direct description, relations between the objects and logical conditions (BAATZ et al., 2001). Features directly describing an object include, among others, average values of spectral reflections, shape parameters and texture. Moreover, there is also information connected with 
the segmentation level and thematic attributes, provided that the classification process uses GIS thematic layers. The texture of objects is defined on the basis of objects of the lower level of segmentation and the Haralick functions (HALL-BEYER, 2005), computing the texture parameters.

Parameters of the relation between objects describe their mutual location within the particular segmentation levels and between the lower and higher levels. The examples could be the definition of required length of the border between a neighbouring object connected with a particular class, the number of lower-level objects within a given object or a reference to results of the higher-level object classification. Logical operators enable, for instance, the creation of constructions based on the degree of classifications of objects to particular classes.

A particularly valuable feature of the eCognition software is the capability of defining custom functions, which are equally significant in the process of classification as the standard parameters. Custom functions can refer directly to object properties and the relations between objects, which enables the realisation of complex classification functions.

In the object-oriented classification of the eCognition software, the fuzzy set theory has been applied, which - unlike logical operations - is not limited to "yes" and "no" values. Possible results range between the values of $<0,1>.0$ value is interpreted as the "no" answer, while 1 value as the "yes" answer. The values between 0 and 1 refer to intermediate answers, whose value is calculated on the basis of the membership function value (BAATZ et al., 2001; JENSEN, 1996). Such a procedure standardises the values of diverse properties of objects, enables their direct comparison and facilitates the creation of a hierarchical description of classes.

Every object defined in the course of segmentation can be classified according to its parameters, i.e. on the basis of preset criteria of parameter values or using the Nearest Neighbour method $(\mathrm{NN})$. The classification based on the Nearest Neighbour method is a counterpart of the supervised classification. Objects are classified by comparing their properties with selected sample objects.

Another important feature of the eCognition software is the hierarchical structure of definition of classes, enabling the inheritance of classification properties, owing to which the description of classes has the form of mutual, logically ordered relations. The classes on the last level in the hierarchy automatically inherit the properties of higher classes on which they are dependent in the process of classification. Moreover, regardless of the inheritance mechanisms, it is possible to create groups of semantically matching classes.

Currently, one of the major applications of the object-oriented classification is the classification of high-resolution images, whose processing with traditional methods is particularly inefficient. Object-oriented approach enables identification of urban infrastructure in images of 1-metre resolution. (DE KOK et al., 2003; EHLERS et al., 2006; REGO and KOCH, 2003). The object-oriented classification often uses auxiliary data, i.e. a numerical model of the area (HOFMANN, 2001a,b; 
NeUBERT, 2001). The new technique is successfully applied in the research of forest (DE KOK et al., 2005; TIEDE et al., 2004; WĘŻYK and BEDNARCZYK, 2005; WĘŻYK et al., 2004). The works are being conducted in the field of hyperspectral (GREIWE and EHLERS, 2005), radar (KELLNDORFER and UlABY, 2003) and aerial (KRESSLER et al., 2005; SYED et al., 2005) image classification. Mediumresolution images will also be classified using the object-oriented method (GOMES and MARCAL, 2003; Mitri and GITAS, 2002; LEWIŃSKI, 2006; ROSSNER and BOCK, 2005).

\section{SATELLITE IMAGE LANDSAT ETM+ AND STUDY AREA}

Object oriented classification has been performed on a Landsat ETM+ satellite image collected on 7 May 2000. Pre-processing of the Landsat image involved the preparation of satellite data for classification. To this end, atmospheric correction and data fusion of multispectral data with the panchromatic channel were performed.

Atmospheric correction was performed using ATCOR2 software, a module of the PCI Geomatica image processing system. A standard definition of the atmospheric conditions for the spring season and agriculture-dominated areas was applied. Multispectral data of the Landsat ETM+ image were fused with the panchromatic channel using the PanSharp algorithm by ZHANG $(1999,2002)$, a module of the PCI Geomatica software. Using the PanSharp algorithm, three multispectral channels No. 2, 3 and 4, which from the spectral perspective matched the range of the panchromatic channel, were selected for fusing. As a result, three new channels were obtained: PanSharp2, PanSharp3 and PanSharp4.

The study was selected on a subset of Landsat ETM+ image showing the area of $423 \mathrm{~km}^{2}$, situated in central Poland, in the region of Masovian Lowland (Nizina Mazowiecka) near Warsaw (Picture 1). In the centre of the area, between the Vistula and Narew rivers, there is the city of Legionowo (49,000 citizens). The area has coniferous and deciduous forests, arable lands, grasslands and built-up areas, mainly of discontinuous development. Rural areas are mainly scattered: the fields of arable land are small, often below 1 ha, adjoining the green areas. There is an artificial reservoir Zalew Zegrzyński on the Narew River of the area of over $30 \mathrm{~km}^{2}$.

\section{OBJECT-ORIENTED CLASSIFICATION OF LANDSAT ETM+ IMAGE}

Segmentation is the first step of object oriented classification. It was prepared based on panchromatic and PanSharp channels. Selection of the parameters of segmentation was connected with classification assumption - identification of objects of minimum area of 4 ha for all classes and 1 ha for water and built-up areas. 


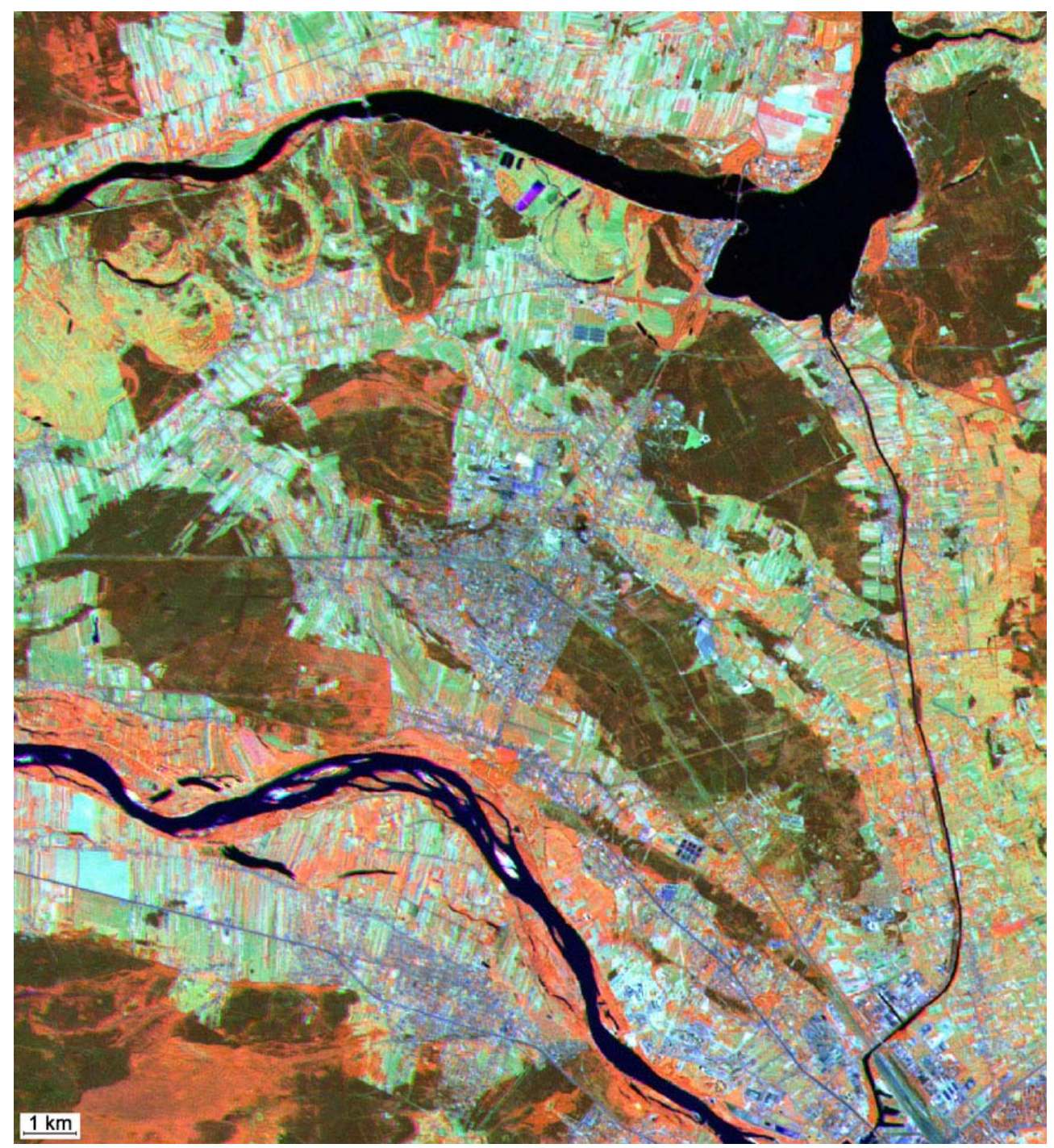

Picture 1. Study area, colour composite $(4,5,3)$ of Landsat ETM+ satellite image

The first level of segmentation was performed exclusively on the basis of the panchromatic channel, using a low scale parameter of the value of 10 and high values of color and compactness coefficients, 0.9 and 1.0 respectively. Image of the study area was divided into 84183 objects of consistent shapes. The second level of segmentation, prepared on the basis of the first one, is characterised by much higher scale parameter of the value of 23 and lower color and compactness parameters of the same value of 0.8 . For the PanSharp3 channel, weight 2 was applied, which - in this set of data - performed an averaging role for the PanSharp4 chan- 
nel, which has high standard deviation. 4269 objects were identified in the second level. The applied parameters enabled correct separation of the objects to be classified afterwards, including the objects of linear character (Picture 2).
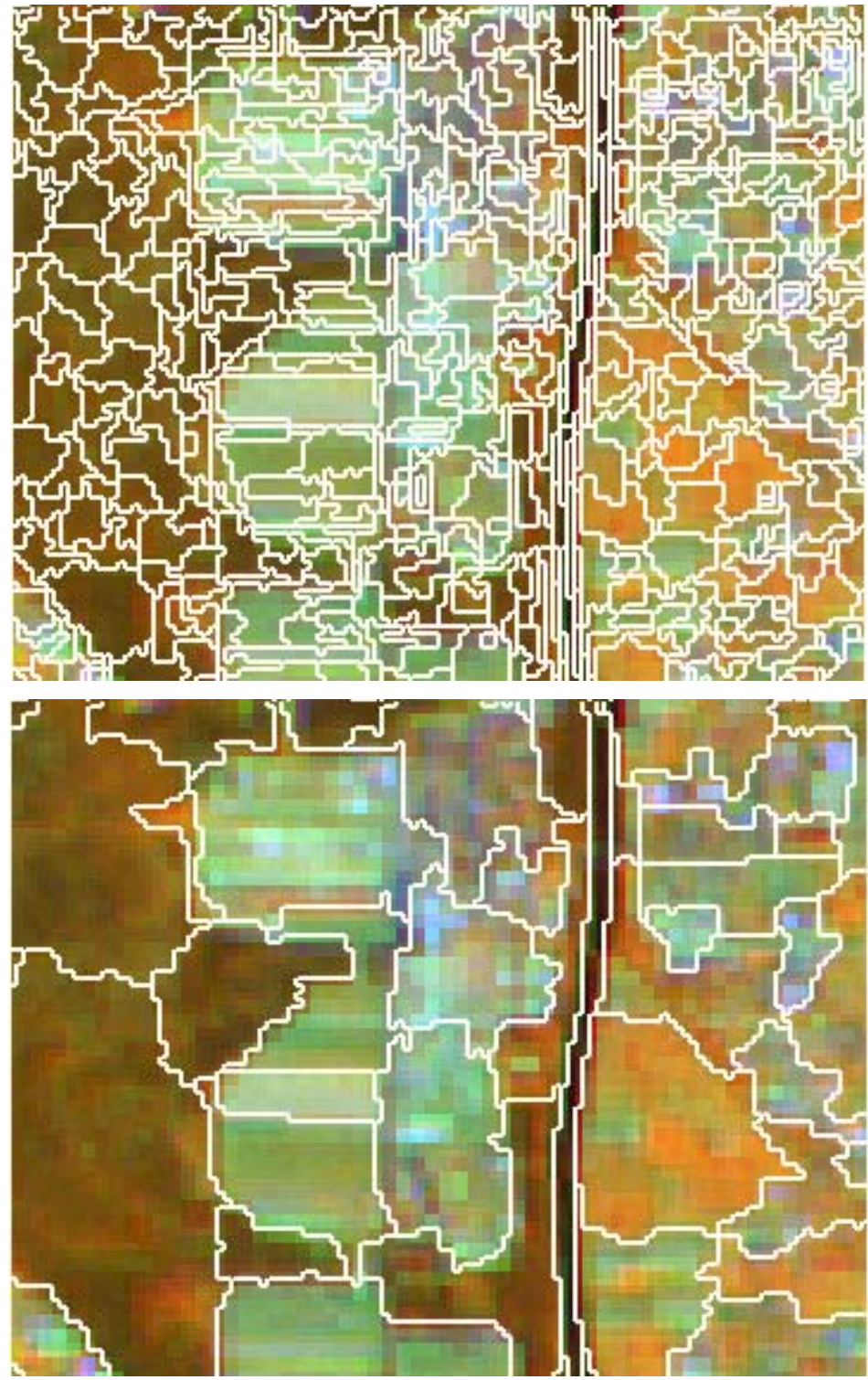

Picture 2. Segmentation of classified image, level 1 (up) and level 2 (down). Subset of study area 
Application of PanSharp2, PanSharp3 and PanSharp4 channels in segmentation seems entirely justified. They contain a sum of information connected with multispectral channels and the panchromatic channel. Performed trials indicated that fused data increased the precision of identification of objects, as compared to multispectral data.

Classification of the Landsat ETM+ was performed on the basis of the second segmentation level. For the purpose of identification of land cover classes, the following functions of eCognition software were applied: Standard Nearest Neighbour (STD.N.N.) and parametric criteria. Selection of the classification parameters applied in the nearest neighbour method was preceded by the analysis of discrimination of land cover classes. The total of 14 parameters connected with the panchromatic channel, multispectral channels and PanSharp channels were tested. For the purpose of specifying the discrimination parameters, the "Feature Space Optimization" function of the eCognition software was used.

Performed analyses proved that the panchromatic channel and PanSharp channels do not exert significant influence on discrimination of the defined land cover classes. However, it must be underlined that relatively best results were obtained for the PanSharp4 channel, which has the highest level of standard deviation. Eventually, six parameters were chosen for application to STD.N.N. classification: average spectral values of channels 4,5 and 7, RATIO function applied to channels 3 and 7, GLCM entropy of channel 2.

The process of classification involved also parametric criteria existing independently or together with STD.N.N.. To this end, the criteria of object size, distance, shape, border and border length, belonging to another class and average values and standard deviations connected with the selected channels were applied. 18 land cover classes were classified. Classified classes are presented in Table 1. In respect of spectral similarity, some classes cannot be identified using traditional classification methods, which rely exclusively on the analysis of spectral values of satellite image pixels.

The classification image obtained as a result of the object oriented classification was generalised and tested using a method of visual interpretation. The same procedures as in the case of classification ASTER images were applied (LEWIŃSKI, $2006,2005)$. The classification image was prepared using an algorithm aimed at obtaining a database similar to the one resulting from traditional visual interpretation.

Generalisation was based on the classification data in raster format in the PCI Geomatica software environment. For classes connected with built-up area and water, $\mathrm{WU}=1$ ha (Working Unit) was adopted, while for other classes, WU was 4 ha. Objects of the area below WU were included to larger neighbouring objects.

Next, raster to vector conversion was performed. The edges of objects along the edges of satellite image pixels were smoothed (using the feature of PCI Geomatica) in order to make them similar to the borders of visual interpretation. 
Table 1. Land cover and land use classes classified on Landsat ETM+ image using object-oriented tools

\begin{tabular}{cl}
\hline No. & \\
\hline 1 & Built-up areas with apartment blocks \\
2 & Discontinuous built-up areas \\
3 & Rural discontinuous built-up areas with family houses \\
4 & Industrial areas \\
5 & Liquid waste dumps \\
6 & Construction sites \\
7 & Green urban areas \\
8 & Arable land - large blocks \\
9 & Arable land - small blocks \\
10 & Greenhouses \\
11 & Grasslands \\
12 & Agricultural areas with natural vegetation \\
13 & Deciduous forest \\
14 & Coniferous forest \\
15 & Mixed forest \\
16 & Transitional woodland \\
17 & Beaches \\
18 & Water courses and bodies \\
\hline
\end{tabular}

Assessment of classification was performed using a method of visual interpretation according to the way adopted by CORINE 2000 project (NUNES DE LIMA, 2005). The interpreter adjusted the edges of objects and the codes of classes directly on the screen displaying the vector database and the satellite image. As a result of interpretation, the so-called change layer was obtained, which provided information about the correctness of the classification.

Total accuracy of the classification reached $94.6 \%$; there was also a high value of the statistics $\mathrm{K}_{\mathrm{HAT}}=93.9 \%$ (CONGALTON, 1991). Theoretically, the majority of mistakes may result from the fact that the classified image was taken in May. In the spring season, vegetation has a high concentration of chlorophyll, which causes a decreased spectral diversity among so-called green classes. It is also visible in the case of visual interpretation. On the other hand, mistakes in classification of rural discontinuous built-up areas are mainly connected with scattered development; in the case of more dense urban built-up areas, the accuracy was much higher. After consideration of change in layer information the final land cover data base has been prepared (Picture 3). 


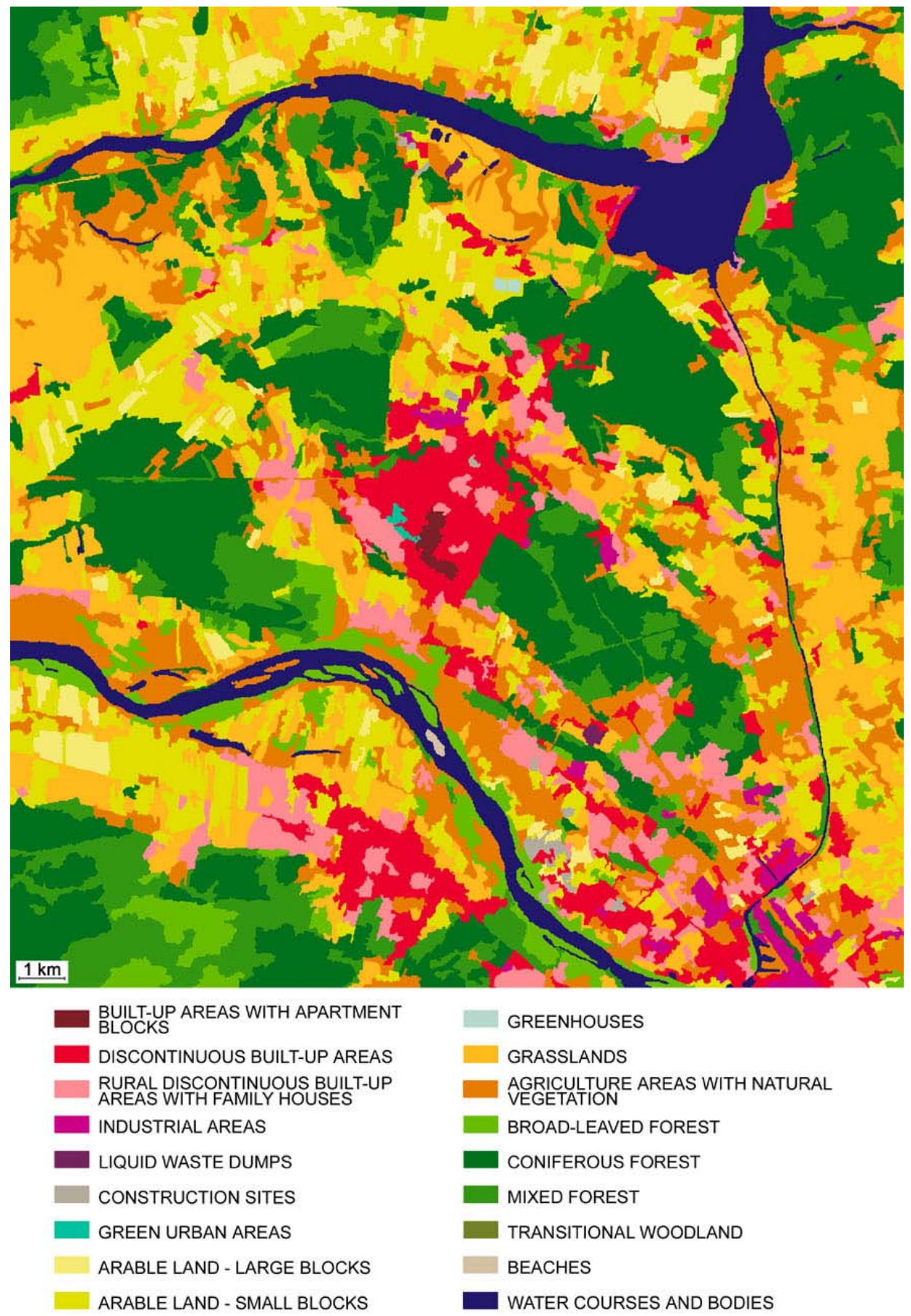

Picture 3. Object-oriented classification, image of the final data base 


\section{COMPARISON OF OBJECT-ORIENTED CLASSIFICATION WITH TRADITIONAL PIXEL-BASED CLASSIFICATION}

In order to compare the object-oriented classification with the traditional classification, the pixel-based classification was performed on the basis of the same data. The so-called hybrid classification model (Image Analyst, 2002) was applied, consisting of two parts: supervised and unsupervised classification. First of all, supervised classification is performed on the basis of training fields defined by the operator; next, the unclassified pixels are classified using the unsupervised method. Adoption of such a procedure was determined by specific character of the study area, characteristic for highly scattered land cover forms. In numerous cases, it makes the definition of representative training fields very difficult or even impossible.

Performed analyses resulted in identification of training fields for 8 classes: built-up area, arable land with vegetation, arable land with no vegetation, grasslands, deciduous forest, coniferous forest, liquid waste dumps and water. In the further stage of classification, the classes of "arable land with vegetation" and "arable land with no vegetation" were merged to one class of arable land. Training fields for the class of mixed forest were not defined, as in the case of manual marking of representative areas in the colour image, this class is a frequent cause of mistakes, connected with identification of mixed deciduous and coniferous trees. The training fields included a small, but identifiable class of liquid waste dumps.

A set of optimum channels enabling the most effective identification of training fields was defined using the average value transformed divergence (JENSEN, 1996). Multispectral, panchromatic data and PanSharp channels were analysed. The channels: 2, 3, 4, 5 and 7 were selected as the best set of classification data.

The supervised classification was carried out using the maximum probability method. First attempts resulted in identification of an excessive number of "built-up area" class pixels in the classification image. Adjustment of training fields and using a very low weight coefficient for this class did not result in a satisfactory improvement. Therefore, it was decided to neglect this class at that stage of classification and another classification was performed on the basis of training fields of the remaining 7 classes.

The second stage involved the unsupervised classification of pixels that had not been classified so far. The parameters of spectral classes were defined using the Competitive Training algorithm (HUNG, 1993; Image Analyst, 2002). 15 spectral classes were automatically defined and the classification using the maximum probability method was performed. Next, spectral classes were grouped into thematic classes. The total of 6 thematic classes were identified: "arable land", "grasslands", "deciduous forest" and "water", corresponding to the classes defined in the course of the supervised classification, as well as two classes that had not been identified before: "built-up area" and "mixed forest". The final stage of the hybrid 
classification involved merging the supervised classification and the unsupervised classification.

As in the case of the object-oriented classification, the result of the pixel-based classification was generalised. Generalisation followed the same principles as in the case of the object-oriented classification, based on the working unit of 1 ha for built-up area and water and 4 ha for the remaining classes. As a result of the generalisation, the class of liquid waste dumps, which turned out to be too scattered, was eliminated and also the number of unclassified pixels was reduced. Comparative analyses showed that the generalisation resulted in changes in classification in $26.7 \%$ of the study area, which indicates high degree of scattering of classes, as compared to the adopted parameters of generalisation. The change in the degree of detail of study area's classification, as compared to the classification data is clearly visible. Moreover, the well-defined structure of the Zegrzyński Channel, connecting Zalew Zegrzyński with the Vistula River, was interrupted in several places. The classification image after the generalisation is presented in Picture 4.

The process of generalisation is also affected by typical errors of pixel-based classification, connected with attributing so-called edge pixels, located on the borders of forests, and pixels connected with communication routes to the class of "built-up area". In numerous cases, such a misclassification of single pixels results in breaking the continuity of classes and their generalisation, if the surface of pixel groups is smaller than the assumed working unit. The changes after the generalisation are too serious to treat this method as a way to obtain reliable information about land use and land cover with 4-ha degree of detail.

The assessment of accuracy of the pixel-based classification was performed, by comparing this classification with the object-oriented classification. The generalised result of the hybrid classification was compared to the object-oriented classification, to which the changes introduced by the interpreter during the visual verification were applied. In order to obtain reliable results of such comparison, the problem of different number of classes identified during the two classifications had to be solved. It required an aggregation of selected classes of the object-oriented classification from 18 into 7 . The aggregation of classes was determined mostly by spectral properties and - in the case of smaller classes - thematic criterion. However, two classes of the object-oriented classification: "Arable land - small blocks" and "Agricultural areas with natural vegetation" were not possible to be aggregated to classes of the pixel-based classification, as these two classes are not spectrally homogenous. The former represents the so-called mosaic structure of crops, within which there are minor structures of arable lands and grasslands. The latter is associated mainly with grasslands, but within its borders, there are also small areas of arable land, forest and water. In both cases, isolation of these subclasses is not possible; at the same time, these classes constitute a large part of the study area and have influence on the assessment of the compared classification. In order to solve this problem, two methods were adopted. The first one assumed that all classes of 


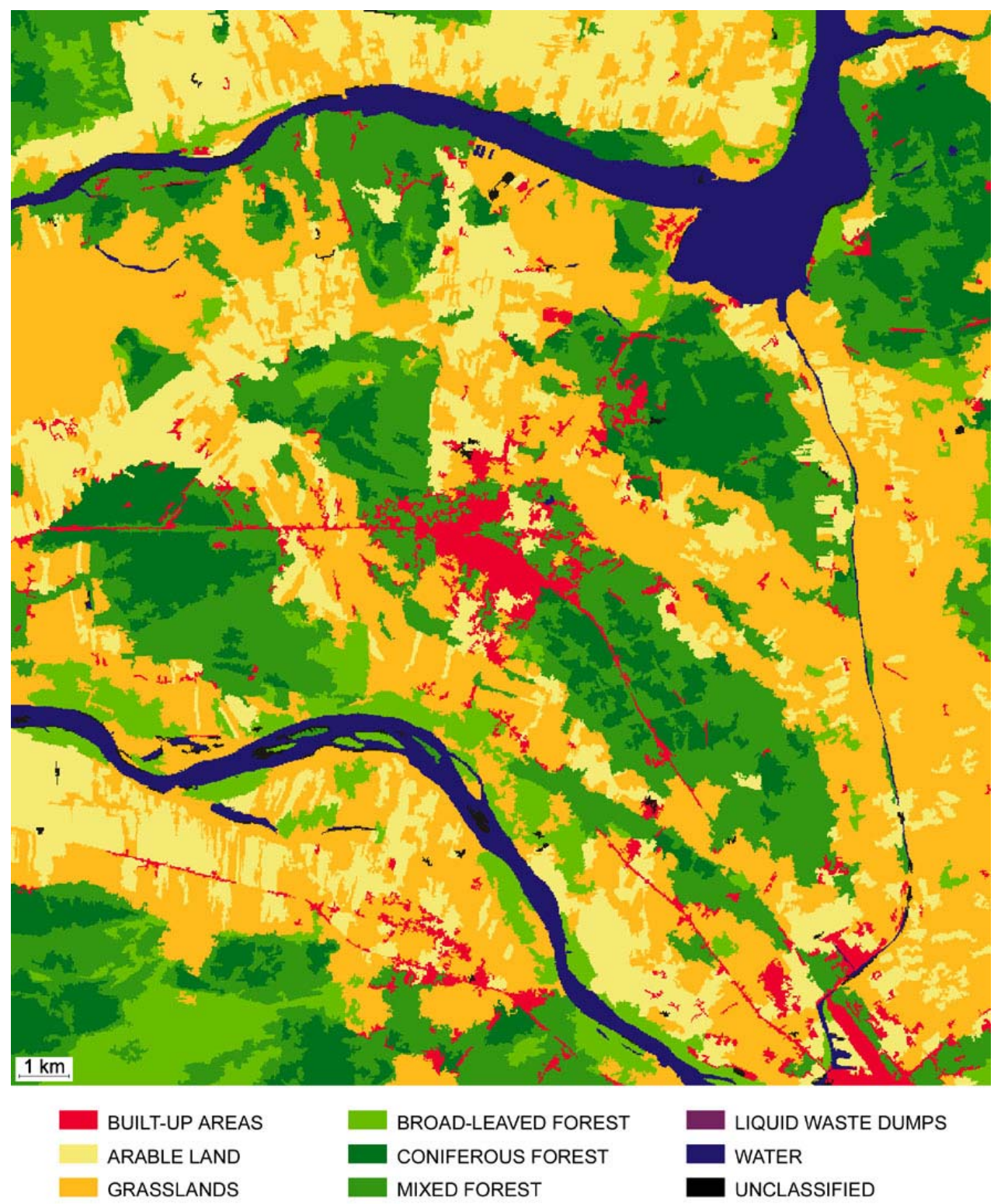

Fig. 4. Hybrid classification after the generalisation

the pixel-based classification identified within these classes were identified correctly. The second one ignored these areas in the course of the comparative analysis. 
As expected, higher accuracy of the pixel-based classification was achieved using the first method: it reached $72 \%$. The second method resulted in the total accuracy of only $61 \%$. In both cases, the $\mathrm{K}_{\mathrm{HAT}}$ statistic values were also low: 0.66 and $0.54 \%$. The results of the comparative analysis indicate very low accuracy of the pixel-based classification, as compared with the results of the object-oriented classification.

\section{CONCLUSION}

Applied tools of object-oriented classification enabled the identification of 18 classes. Subsequent generalisation caused changes only to the area constituting $1.1 \%$ of the entire study area. Classification accuracy assessment using the method of visual interpretation and creation of the final land cover and land use database was final stage of the works. The accuracy for the entire study area reached over 94\%.

Traditional pixel-based classification was performed using hybrid classification. The pixel-based approach enabled identification of only 8 classes. In the process of generalisation, based on the same principles as in object-oriented classification, $26 \%$ of the area of the analysed image was changed. The accuracy of pixel-based classification, assessed by comparing the post-generalisation image to the database obtained after the visual verification of object-oriented classification reached $72 \%$ and $61 \%$, depending on the comparison method applied.

The results of comparing these two methods of classification prove the great advantage of object-oriented classification over traditional pixel-based approach. The tools of object-oriented classification did not only enable the identification of twice as many classes as those of the pixel-based approach, but also provided a high accuracy classification.

\section{REFERENCES}

1. Baatz M., Banz U., Dehghani S., Heynen M., Holtje A., Hofmann P., Lingenfelder I., Mimler M., Sohlbach M., Weber M., Willhauck G., 2001. eCognition user guide. Definiens imaging $\mathrm{GmbH}$.

2. BAATZ M., SchAPE A., 1999. Object-oriented and multi-scale image analysis in semantic networks. Proc. $2^{\text {nd }}$ Intern. Symp.: Oprerationalization of remote sensing, 16-20 Aug., ITC, The Netherlands.

3. BAATZ M., SCHAPE A., 2000. Multiresolution segmentation - an optimization approach for high quality multi-scale image segmentation. Angewandte Geogr. Informatiosverarbeitung 12, Beitrage zum AGIT - Symposium, Salzburg.

4. BlaschKe T., LANG S., LoRUP E., Strobl J., Zeil P., 2000. Object-oriented image processing in an integrated GIS/Remote Sensing environment and perspectives for environmental applications. Environmental information for planning, Politics and the public. Metropolis Verlag, Marburg, vol. 2: $555-570$. 
5. Congalton R.G., 1991. A review of assessing the accuracy of classifications of remotely sensed data. Rem. Sens. Env. 7: 35-46.

6. Ehlers M., Michel U., Bohmann G., Tomowski D., 2006. Decision based data fusion techniques for the analysis of settlement areas from multisensor satellite data. Proc. ASPRS 2006 Ann. Conf. Reno, Nevada; May 1-5.

7. Gomes A., MARCAL A.R., 2003. Land cover revision through object based supervised classification of ASTER data. Proc. ASPRS 2003 annual conference, Anchorage, USA; May 5-9.

8. GonZalez R. C., Wintz P., 1977. Digital image processing. Addison-Wesley Publishing Company.

9. GReiwe A., Ehlers M., 2005. Combined analysis of hyperspectral and high resolution image data in an object oriented classification approach. Proc. ISPRS WG VII/1 "Human Settlements and Impact Analysis" 3rd Intern. Symp. Rem. Sens. Data Fusion over Urban Areas (URBAN 2005) and 5th Intern. Symp. Rem. Sens. Urban Areas (URS 2005). Tempe, AZ, USA. March 14-16.

10. Hall-Beyer M., 2005. GLCM texture: a tutorial. http://www.fp.ucalgary.ca/mhallbey/tutorial.htm

11. HofmAnN P., 2001a. Detecting urban features from IKONOS data using an object-oriented approach. Rem. Sens. Photogrammetry Soc. (Editor): Proc. First Ann. Conf. Rem. Sens. Photogrammetry Society 12-14 September: 28-33.

12. Hofmann P., 2001b. Detecting buildings and roads from IKONOS data using additional elevation information. GeoBIT/GIS 6: 28-33.

13. Hung C-C., 1993. Competitive learning networks for unsupervised training. Intern. J. Rem. Sens. vol. 14 no. 12 : $2411-2415$.

14. Image Analyst, 2002. IA User's Guide. Z/I Imaging Corporation.

15. JENSEN J.R., 1996. Introductory digital image processing, a remote sensing perspective. Second edition. Prentice Hall, Upper Saddle River, New Jersey.

16. Kellndorfer J.M., Ulaby F.T., 2003. Forest biomass inversion from SAR using object oriented image analysis techniques. In: Proc. IGARSS 2003 IEEE, July 2003, Toulouse.

17. KreSSler, F.P., SteINNOCHER K., FrANZEN M., 2005. Object-Oriented Classification of Orthophotos to support update of Spatial Databases. Proc. IGARSS 2005 Symp. Seoul, Korea. July 25-29, 2005.

18. De Kok R., Buck A., Schneider T., Ammer U., 2000. Analysis of image objects from VHR imagery for forest GIS updating in the Bavarian Alps. Proc. ISPRS Amsterdam, July 2000, Working Group III/5.

19. De KoK R., Wever T., Fockelmann R., 2003. Analysis of urban structure and development applying procedures for automatic mapping of large area data. In: Remote sensing of urban areas: 41-46.

20. De KoK R., KozıoŁ K., WężYK P., 2005. Zastosowanie klasyfikacji obiektowej wysokorozdzielczych obrazów teledetekcyjnych oraz analiz przestrzennych GIS w kartowaniu drzewostanów. (Application of object-oriented classification of high resolution remote images and of spatial GIS analyses in mapping tree stands). Rocz. Geomat. t. 3 z. 4: 99-108.

21. LEWIŃSKI S., 2005. Klasyfikacja obiektowa narzędziem wspomagającym proces interpretacji zdjęć satelitarnych. (Object-oriented classification as a tool supporting the interpretation of satellite images) Rocz. Geomat. t. 3 z. 2: 97-106.

22. LEWIŃSKI S., 2006. Land use classification of ASTER image - Legionowo test site. Proc. of the $25^{\text {th }}$ Symp. Eur. Assoc. Rem. Sens. Laborat. Porto, Portugal, 6-9 June 2005. Global Developments in Environmental Earth Observation from Space.

23. MitRi G.H., GitAS I.Z., 2002. The development of an object-oriented classification model for operational burned area mapping on the Mediterranean island of Thasos using Landsat TM images. Proc. Intern. Conf. Forest Fire Research, Luso - Coimbra, Portugal, 18-23 November, 2002.

24. NeUBERT M., 2001. Segment-based analysis of high resolution satellite and laser scanning data. In: Sustainability in the information society. Eds. L.M. Hilty, P.W. Gilgen. Proc. Intern. Symp. Inform. Env. Protect. Zurich, October 10-12, 2001. Marburg: 379-386. 
25. Nunes DE Lima M. V., 2005. CORINE Land Cover updating for the year 2000. IMAGE2000 and CLC2000, products and methods. JRC-IES.

26. REGO F.L., КосH B., 2003. Automatic classification of land cover with high resolution data of the Rio de Janeiro city Brazil comparison between pixel and object classification. In: Remote sensing of urban areas. Ed. J. Carstens: 153-157.

27. Rossner G., Bock M., 2005. The aptness of landcover classifications for regional environmental planning: new orientation through objects? New strategies for European remote sensing. Proc. $24^{\text {th }}$ ERSeL Symposium, Dubrovnik, Croatia, 25-27 May 2004.

28. SCHNEIDER W., STEINWENDNER J., 1999. Landcover mapping by interrelated segmentation and classification of satellite images. Intern. Arch. Photogramm. Rem. Sens. (IAPRS) vol. 32 W6 7-4-3.

29. Syed S., DARE P., JONES S., 2005. Automatic classification of land cover features with high resolution imagery and lidar data: an objectoriented approach. Proceedings of SSC2005 Spatial Intelligence, Innovation and Praxis: The national biennial Conf. Spatial Sci. Inst. September, 2005. Melbourne, Spatial Sciences Institute.

30. Tiede D., Heurich M., BlaschKe T., 2004. Object-based semi automatic mapping of forest stands with Laser scanner and Multi-spectral data. Intern. Arch. Photogramm. Rem. Sens. Spatial Inform. Sci. vol. 36-8W2, Freiburg: 328-333.

31. WęŻYK P., DE KoK R., ZAJĄCZKOWSKI G., 2004. The role of statistical and structural texture analysis in VHR image analysis for forest applications - A case study on Quickbird data in Niepolomice Forest. In: Angewandte Geoinformatik. Eds. J. Strobl, T. Blaschke, G. Griesebner. Beiträge zum 16. AGIT-Symposium Salzburg 2004, Heidelberg, H. Wichmann Verlag: 770-775.

32. WęŻYK P., BEDNARCZYK P., 2005. Testowanie metod i algorytmów klasyfikacji wysokorozdzielczych zobrazowań satelitarnych Puszczy Niepołomickiej. (Testing methods and algorithms for the classification of high resolution satellite images of Niepołomicka Forest). Rocz. Geomat. t. 3 z. 2: $163-172$.

33. ZHANG Y., 1999. A new merging method and its spectral and spatial effects. Intern. J. Rem. Sens. vol. 20 No. 10: 2003-2014.

34. ZHANG Y., 2002. Problems in the fusion of commercial high-resolution satellite images as well as Landsat 7 images and initial solutions. Intern. Arch. Photogramm. Rem. Sens. (IAPRS) vol. 34 p. 4.

\section{STRESZCZENIE}

\section{Klasyfikacja obiektowa zdjęcia satelitarnego Landsat ETM+}

\section{Słowa kluczowe: klasyfikacja obiektowa, Landsat ETM+, użytkowanie ziemi}

W artykule przedstawiono wyniki klasyfikacji obiektowej zdjęcia satelitarnego Landsat ETM+, uzyskane z zastosowaniem specjalistycznego oprogramowania eCognition. Klasyfikację wykonano na przykładzie zdjęcia zarejestrowanego 7 maja 2000 r., obrazującego obszar badawczy o powierzchni $423 \mathrm{~km}^{2}$, znajdujący się w granicach powiatu legionowskiego w pobliżu Warszawy.

Proces klasyfikacji obiektowej polega na rozpoznaniu obiektów, którymi są grupy pikseli spełniające założone kryterium jednorodności. Granice obiektów zostały zdefiniowane w czasie segmentacji zdjęcia, wykonanej na podstawie wartości pikseli kanału panchromatycznego skanera ETM+ oraz danych uzyskanych w wyniku połączenia wybranych kanałów wielospektralnych z kanałem panchromatycz- 
nym. Zastosowane metody klasyfikacyjne, związane nie tylko z wartościami spektralnymi charakteryzującymi poszczególne obiekty, lecz również z kryteriami parametrycznymi, umożliwiły identyfikację 18 klas pokrycia i użytkowania ziemi. Następnie wynik klasyfikacji został przetworzony funkcjami: generalizacji, konwersji formatu danych oraz poddany weryfikacji. Generalizację wykonano z zastosowaniem jednostki odniesienia wynoszącej 1 ha dla klas zabudowy i wody oraz 4 ha dla pozostałych klas. Następnie format klasyfikacji został zmieniony z rastrowego na wektorowy, w którym wykonano wygładzenie granic wydzieleń. Klasyfikacja została zakończona weryfikacją wektorowej bazy danych metodą interpretacji wizualnej. Całkowita dokładność klasyfikacji została oceniona na poziomie 94.6\%. Po uwzględnieniu zmian wprowadzonych w czasie weryfikacji uzyskano końcową postać bazy danych.

Wyniki klasyfikacji obiektowej zostały porównane $\mathrm{z}$ wynikami tradycyjnej (pikselowej) klasyfikacji, wykonanej z zastosowaniem algorytmu tzw. klasyfikacji hybrydowej, składającej się z następujących po sobie klasyfikacji nadzorowanej i nienadzorowanej. Rozpoznano jedynie 8 klas pokrycia i użytkowania ziemi. Dokładność tradycyjnej klasyfikacji oceniono przez porównanie jej z wynikami klasyfikacji obiektowej. Uzyskano wyniki na niskim poziomie, wynoszącym jedynie 72 i $61 \%$, w zależności od przyjętej metody oceny.

Reviewers:

Received 20.10.2006

Dr Krzysztof Kosiński

Prof. Jan Olędzki 